\title{
Vibrio spp. AND Salmonella spp., PRESENCE AND SUSCEPTIBILITY IN CRABS Ucides cordatus
}

Regine H.S.F. VIEIRA(1), Elenice Araújo de LIMA(2), Dannielle Batista Rolim SOUSA(3), Eliane Falavina dos REIS(4), Renata Garcia COSTA( 4) \& Dália dos Prazeres RODRIGUES(4)

\begin{abstract}
SUMMARY
The presence of Vibrio spp. and Salmonella spp. in crabs marketed at the Bezerra de Menezes Ave., Fortaleza, State of Ceará, Brazil, was assessed between February and May, 2003. The number of individuals sampled in each one of the fifteen weekly samplings ranged between four and eight. Seven strains of Salmonella, from four different samplings, were identified, being five of them identified as serotype $S$. Senftenberg and two as $S$. Poona. All strains of Salmonella were sensitive to the tested anti-microbial drugs, with the exception of tetracycline and nalidixic acid, for which an intermediary sensibility was found. The MPN's for Vibrio ranged between 110/g and 110,000/g. Of the forty five Vibrio strains isolated from the crab samples, only 10 were identified up to the species level: two V. alginolyticus and eight V. parahaemolyticus. Bacteria belonging to the Enterobacteriaceae and Pseudomonaceae families were also identified, namely Escherichia coli, Klebsiella pneumoniae, Enterobacter cloacae, Pantoea agglomerans and Pseudomonas aeruginosa. The proper cooking of the animals is recommended in order to avoid problems for the consumers of this crustacean.
\end{abstract}

KEYWORDS: Crabs; Vibrio spp.; Salmonella spp.; Susceptibility.

\section{INTRODUCTION}

Crabs are one of the most important natural resources in the estuarine regions of the Brazilian coast. They can be intensely exploited without reaching an overfishing threshold, mainly because the picking method allows the identification of the female individuals, different in size than the males, and their release back into the environment .

Every week, a great quantity of crabs are consumed in Ceará State, Brazil, most of which are hand-picked at the Parnaiba river delta ${ }^{17}$ and afterwards transported overland in trucks to the marketing places to be sold at Bezerra de Menezes Avenue, one of the most important selling points in Fortaleza city. The crabs are transported without any hygienic control, with the animals packed in fabric bags along with the mud residues of the mangroves they were taken from and, when they finally arrive, are left exposed for marketing, without any preventive hygienic treatment except for the washing done by the consumer himself.

Bacteria from genus Salmonella are the main etiologic agents of Food Transmitted Diseases (FTD) worldwide, being an important social and economic problem ${ }^{2}$. Each year, from 800,000 to 4 million cases of infective diseases caused by non-typhoid Salmonella are estimated to occur in the United States. From those cases, about 500 deaths are caused by these infections and children are more frequently affected ${ }^{4}$. HOFER \& REIS $^{9}$ reported 25 events of food-related infections between 1982 and 1991 in the Brazilian southeastern and southern regions, each and every one of them being caused by Salmonella, being $S$. Typhimurium the most common $(52 \%)$.

Despite the fact that Salmonella is not normally isolated from fish and bivalves captured in the open sea, it can be found in marine products captured in contaminated waters.

Studies regarding the presence of Vibrio parahaemolyticus, a public health threat as the cause of gastroenteritic outbreaks in human populations, began after this bacterium was isolated from fish in several countries (United States, Brazil, Japan) ) $^{1,12,26}$. Therefore, the aim of this study was to assess the degree of Salmonella (presence or absence) and Vibrio parahaemolyticus contamination in the marketed crabs at Fortaleza, Ceará State, Brazil.

\section{MATERIAL AND METHODS}

Sampling: Fifteen weekly samplings were performed between February and May, 2003 (between four and eight live crabs (Ucides cordatus) each time, depending on their size). All of the 90 sampled animals were brought to the Laboratory of Fish and Environmental Microbiology of Instituto de Ciências do Mar (LABOMAR), Universidade Federal do Ceará, where they were killed and analyzed as planned.

Sample preparation: The crabs were scrubbed under a flux of tap

(1) Marine Science Institute, Federal University of Ceará, CE, Brazil.

(2) Departament of Fisheries Engineering, Federal University of Ceará, CE, Brazil

(3) Fisheries Engineer, Federal University of Ceará, CE, Brazil

(4) Oswaldo Cruz Institute, Rio de Janeiro-RJ, Brazil

Correspondence to: Dr. Regine H. S. dos Fernandes Vieira, Av. da Abolição 3207, 60165-081 Fortaleza, Ceará, Brazil. E-mail: regine@labomar.ufc.br 


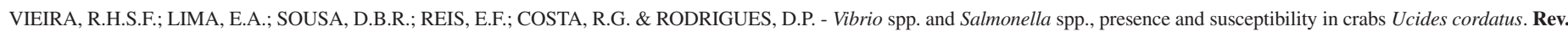
Inst. Med. trop. S. Paulo, 46(4):179-182, 2004.

water in order that any residues present on its carapace were removed. The claws and cephalothorax tissue were tested for the relevant bacteria. For the analysis of Salmonella, $25 \mathrm{~g}$ of tissue were immersed in $225 \mathrm{~mL}$ of lactose broth for 24 hours at $35^{\circ} \mathrm{C}$. For Vibrio parahaemolyticus, 50 $\mathrm{g}$ were homogenized in $450 \mathrm{~mL}$ of a buffered phosphate saline solution (PBS). Dilutions of $10^{-1}$ to $10^{-5}$ were done using $9 \mathrm{~mL}$ of the same saline solution used for the initial culture, with each inoculation done in triplicate, in $1 \%$ peptone water with $3 \% \mathrm{NaCl}$.

The tests used for the determination of Salmonella spp. and Vibrio parahaemolyticus were those of Methods for the Microbiological Examination of Foods ${ }^{6}$. The serology for Salmonella spp. was carried out at Enterobacteria Laboratory/Oswaldo Cruz Foundation, Rio de Janeiro.

Antigenic characterization: After their biochemical confirmation up to the sub-species level, the Salmonella spp. strains were submitted to a conclusive antigenic characterization, through a fast seroagglutination technique ${ }^{18}$, using somatic and flagellar antisera produced by Enterobacteria Laboratory/FIOCRUZ.

Antimicrobial susceptibility test: The susceptibilities to antimicrobials were determined according to National Committee for Clinical Laboratory Standards ${ }^{15}$ recommendations using disks (OXOID) impregnated with Tetracycline $(30 \mu \mathrm{g})$; Ampicillin $(10 \mu \mathrm{g})$; Nalidixic acid $(30 \mu \mathrm{g})$; Chloramphenicol $(30 \mu \mathrm{g})$; Sulfamethoxazol-Trimethoprim $(30 \mu \mathrm{g})$; Nitrofurantoin $(300 \mu \mathrm{g})$; Cephalothin $(30 \mu \mathrm{g})$; Cefoxitin $(30$ $\mu \mathrm{g})$; Ceftriaxone $(30 \mu \mathrm{g})$; Ceftazidime $(30 \mu \mathrm{g})$; Gentamicin $(10 \mu \mathrm{g})$; Streptomycin $(30 \mu \mathrm{g})$; Ciprofloxacin $(5 \mu \mathrm{g})$; Sulfonamide $(23.75 \mu \mathrm{g})$; Enrofloxacin $(5 \mu \mathrm{g})$; Imipenem $(10 \mu \mathrm{g})$; and Aztreonam $(5 \mu \mathrm{g})($ Oxoid). For quality control, E. coli ATCC 25922, E. coli ATCC 35218, P. aeruginosa ATCC 27853, E. faecalis ATCC 29212 and S. aureus ATCC 25923 were tested under the same conditions and antimicrobial drugs.

\section{RESULTS AND DISCUSSION}

Seven out of 44 strains isolated from four different crab samples were confirmed to belong to genus Salmonella (15.2\%). Our results, however, are in disagreement with those reported by REINHARD et al. ${ }^{19}$ who did not find any Salmonella strains in blue crabs (Callinectes sapidus) sampled at Chesapeake Bay, Virginia (USA).

Of the strains isolated from the contaminated samples, five were confirmed as $S$. Senftenberg, which is included among the five most commonly serovars isolated in Brazil in the last five years ${ }^{20,21}$. Two strains were identified as $S$. Poona, with variable incidence in our environment, as it was reported by HOFER et al. ${ }^{10}$. These seven strains were isolated from four crab samplings, meaning that $26.6 \%$ of these crab samplings were contaminated with Salmonella spp.
In São Paulo, between January, 1996 and December, 2000, TAVECHIO et al. ${ }^{24}$ isolated 4,581 strains of Salmonella from non-human source, including foodborne ones, identifying 123 different serotypes: S. Enteritidis (32.7\%), S. Senftenberg (10.3\%), S. Hadar (6.8\%), S. Agona $(5.1 \%), S$. Typhimurium $(2.4 \%)$ and others.

HATHA \& LAKSHMANAPERUMALSAMY ${ }^{8}$ studied 730 fish and 276 crustaceans of the group Brachyura (crabs and swimming crabs) sampled at the fish markets of Coimbatore (Southern India), finding that $14.25 \%$ of the fish and $17.39 \%$ of the crustaceans were contaminated with Salmonella spp. The $S$. Senftenberg serotype was isolated from the crustaceans only, as it was the case of the present study.

Salmonella are widely disseminated microorganisms, able to easily spread to foods from one single contaminated source ${ }^{22}$. That is why the RDC 12 (National Sanitary Surveillance Agency-ANVISA) ${ }^{3}$ has a zero tolerance regarding this particular bacterium. Those microorganisms can be found in marine products captured in contaminated waters despite their not being usually isolated from fish and bivalves captured in the open sea. Salmonella spp. does not present a threat when present in raw products that will be cooked before consumption, since the cooking completely destroys it. Nonetheless, Salmonella can be transferred to other foods by cross-contamination.

The big concern regarding the presence of Salmonella in crabs is that, despite there would be none in the cooked animals, they can be reintroduced from the environment or the raw animals during their processing $^{11}$.

In the U.S.A., different non-typhoid Salmonella serovars have been associated to fish and crustaceans, and $S$. Paratyphi A, S. Enteridis and $S$. Typhi has been the bacterium most associated to mollusc-related diseases $^{7}$.

In a general way, it has been observed that the products not properly cooked or kept under deficient cooling conditions are those that present the greatest risks, with their excessive manipulation increasing such problem. Salmonella-related infections have the special feature that the presence of this organism does not alter the aspect, taste or other characteristics of a contaminated food ${ }^{13}$.

Besides Salmonella, other representatives genera of the Enterobacteriaceae and Pseudomonadaceae families were also isolated from the crab samples (Table 1). Some of them are soil-borne, while others have a fecal origin, showing the poor hygienic conditions of the marketed crabs.

The samples' MPN's for Vibrio ranged between 100/g and 110,000/g, with a high heterogeneity among the different samples. Forty-five strains

Table 1

Species identified in the 15 crab samples (90 animals) marketed at Fortaleza, State of Ceará, Brazil, in 2003

\begin{tabular}{llc}
\hline Family Vibrionaceae & Family Enterobacteriaceae & Family Pseudomonadaceae \\
\hline Vibrio parahaemolyticus & Salmonella spp. & Pseudomonas aeruginosa \\
Vibrio alginolyticus & Escherichia coli, Klebsiella pneumoniae, Enterobacter cloacae, & \\
Vibrio spp. & Pantoea agglomerans, Proteus mirabilis & \\
\hline
\end{tabular}


of Vibrio were isolated, yet only 10 of them were identified to the species level, namely $V$. parahaemolyticus (eight) and $V$. alginolyticus (two).

Vibrio parahaemolyticus has been recognized as an important pathogen of humans and aquacultured animals especially in Asian countries. WONG et al. ${ }^{28}$ examined 668 samples of seafood imported from Hong Kong, Indonesia, Thailand and Vietnam for Vibrio parahemolyticus, recovered strains of this bacterium from 315 (45.9\%) samples. The incidence of $V$. parahemolyticus in products from Hong Kong was markedly higher than the incidence in products from the other countries. The incidence rates in shrimp, crab, snail, lobster, sand crab, fish and crawfish were 75.8, 73.3, 44.3, 44.1, 32.5, 29.3 and 21.1\%, respectively. Likely, MATTÉ et al. ${ }^{14}$ working with pathogenic vibrios present in oysters from the southern coast of São Paulo State quantified $V$. parahaemolyticus that varied from $<3$ to $1,200 / 100 \mathrm{~g}$.

Between 1973 and 1998, forty gastroenteritis outbreaks were reported in the United States, $35 \%$ of which were caused by the consumption of raw oysters and, to lesser extent, of crabs, shrimps, lobsters and octopuses ${ }^{5}$.

THEOPHILO \& VIEIRA ${ }^{25}$, analyzing samples of raw and cooked crab meat sold at three beach restaurants in Praia do Futuro, Fortaleza, State of Ceará, Brazil, were able to confirm the presence of $V$. parahaemolyticus in $42.1 \%$ of the raw samples, and in $32.4 \%$ of the cooked ones.

Vibrio alginolyticus was initially classified as a V. parahaemolyticus biotype. They present a similar C-G percentage, yet having some phenotypic differences, with $V$. alginolyticus showing a saccharose fermentation capacity and growing at $10 \% \mathrm{NaCl}$. V. alginolyticus is autochthonous of the saline environment, and is usually detected in different ecological niches, being more abundant in the northern hemisphere, in the summertime, and a common inhabitant of tropical regions, where it is even part of the normal fish microbiota ${ }^{16}$. As a pathogen to humans, it is usually isolated from infections of cutaneous injuries, acquired in the marine environment.

Despite the high number of Vibrio species detected in the crab's raw meat, including those potentially harmful to humans, it is not possible to establish any correlation to acceptable levels because of the lack of regulatory limits for these organisms ${ }^{3}$ with the sole exception of Vibrio parahaemolyticus, and in this case only for foods intended to be consumed raw, which is not the case of crabs.

We can conclude that the isolation of different Salmonella serovars in the tested crabs is a matter of concern, it shows the influence of sewerage over the sites where the crabs are captured, being such a microorganism a natural inhabitant of the intestinal tract of both humans and animals. Its presence, therefore, indicates a direct or indirect fecal contamination, a situation that can be evidenced by the high frequency of Escherichia coli isolates.

As a cause of human morbidity, its frequency and/or persistence depend, essentially, on the involved serotype, the infecting dose, its ubiquitous characteristics, and the foods' hygienic and sanitary conditions. Regarding the hosts, some individuals are more susceptible to develop a septicemic condition, namely those with immune deficiencies or chronic infections, especially biliar or hepatic, some types of anemia, and HIV-positives ${ }^{27}$.
Although all strains of Salmonella have been sensitive to the tested anti-microbial drugs, with the exception of tetracycline and nalidixic acid, for which an intermediary sensibility was found, such results must be assessed cautiously, since such organisms can easily acquire antimicrobial drug-resistant genes, an evolutionary mechanism to adapt themselves to their surrounding environment, which has serious repercussions over public health ${ }^{23}$.

Since Salmonella was isolated from crabs, it is suggested that a Good Manufactoring Practices (GMP) program should be adopted during the cooking procedures. One should emphasize the importance to avoid live animals contact with the cooking recipients used to prevent crosscontaminations.

\section{RESUMO}

\section{Vibrio spp. e Salmonella spp. em caranguejos, Ucides cordatus}

Foram pesquisadas a presença de Vibrio spp. e de Salmonella spp. em caranguejos comercializados na Av. Bezerra de Menezes, Fortaleza, Ceará, Brasil, no período entre fevereiro e maio de 2003. O número de indivíduos em cada, das quinze coletas realizadas, semanalmente, variava entre quatro e oito dependendo do tamanho dos animais, totalizando um número de 90 (noventa) animais examinados. Foram identificadas sete cepas de Salmonella spp. provenientes de quatro coletas: cinco foram identificadas como sorovar $S$. Senftenberg e duas como $S$. Poona. Todas as cepas de Salmonella, isoladas das amostras de caranguejos, apresentaram sensibilidade aos antimicrobianos testados, com exceção de tetraciclina e ácido nalidíxico para os quais elas apresentaram uma sensibilidade intermediária. Os NMPs para Vibrio spp. variaram entre 110 e $110.000 / g$. Das quarenta e cinco cepas de Vibrio spp. isoladas das amostras de caranguejo, foram identificadas, até espécie, somente 10: duas de $V$. alginolyticus e oito de V. parahaemolyticus. Foram também identificadas bactérias pertencentes às famílias Enterobacteriaceae e Pseudomonadaceae: Escherichia coli, Klebsiella pneumoniae, Enterobacter cloacae, Pantoea agglomerans e Pseudomonas aeruginosa. Recomenda-se que a cocção dos animais seja bem feita a fim de se evitar problemas para os consumidores dos crustáceos.

\section{REFERENCES}

1. ADAMS, M.R \& MOSS, M. - Food Microbiology. 2. ed. Cambridge, Royal Society of Chemistry, 2000.

2. ALVES, L.M.C.; COSTA, F.N. \& SILVA, M.I.S. - Toxinfecção alimentar por Salmonella enteritis: relato de um surto ocorrido em São Luís-MA. Hig. Aliment., 15: 57-58, 2001

3. ANVISA/Agência Nacional de Vigilância Sanitária - Resolução - RDC n ${ }^{\circ} 12$, de 2 de janeiro de 2001. Regulamento técnico sobre os padrões microbiológicos para alimentos. Diário Oficial da República Federativa do Brasil, Brasília, DF, 10 janeiro 2001.

4. CENTERS FOR DISEASE CONTROL AND PREVENTION (CDC) - Salmonella. URL: http:// www.cdc.gov/od/oc/media/fact/salmonella.htm. Accessed in: 16/07/1999.

5. DANIELS, N.A.; RAY, B.; EASTON, A. et al. - Emergence of a new Vibrio parahaemolyticus serotype in raw oysters: a prevention quandary. J. Amer. med. Ass., 284: 1541-1545, 2000.

6. DOWNES, F.P. \& ITO, K. ed. - Compendium of methods for the microbiological examination of foods. 4. ed. Washington, APHA, 2001 


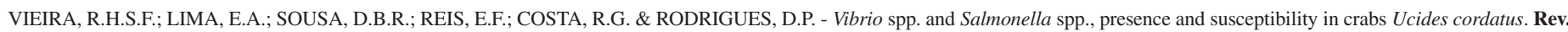
Inst. Med. trop. S. Paulo, 46(4):179-182, 2004.

7. FELDHUSEN, F. - The role of seafood in bacterial foodborne diseases. Microbes Infect., 2: 1651-1660, 2000.

8. HATHA, A.A.M. \& LAKSHMANAPERUMALSAMY, P. - Prevalence of Salmonella in fish and crustaceans from markets in Coimbatore, South India. Food Microbiol., 14: 111-116, 1997.

9. HOFER, E. \& REIS, M.F. - Salmonella serovars in food poisoning episodes recorded in Brazil, from 1982 to 1991. Rev. Inst. Med. trop. S. Paulo, 36: 7-9, 1994.

10. HOFER, E. ; SILVA FILHO, S.I. \& REIS, E.M.F. - Sorovares de Salmonella isolados de matérias-primas e de ração para aves no Brasil. Pesq. vet. bras., 18(1): 21-27, 1998.

11. JACKSON, T.C.; ACUFF, G.R. \& DICKSON, J.S. - Meat, poultry, and seafood. In: DOYLE, M.P.; BEUCHAT, L.R. \& MONTVILLE, T.J. Food microbiology fundamentals and frontiers. Washington, ASM, 1997. p. 83-99.

12. JAY, J.M. - Modern food microbiology. New York, AVI, 2000 .

13. MAGNANI, A.L.; GIOMBELLI, A.; SCHUCK, M.S.; BUSATO, M.A. \& SILVA, N.L. - Incidência de Salmonella e Escherichia coli em carne suína in natura e salame colonial, consumido pela população de Chapecó-SC. Hig. Aliment., 14: 44-47, 2000.

14. MATTÉ, G.R.; MATTÉ, M.H.; RIVERA, I.G \& MARTINS, M.T. - Distribution of potentially pathogenic vibrios in oysters from a tropical region. J. Food protect., 57: 870-873, 1994.

15. NCCLS - Performance Standards of Anti-microbial Susceptibility Testing. M100-S13. v. 22, No. 1, 2003.

16. OLIVER, J.D. \& KAPER, J.B. - Vibrio species. In: DOYLE, M.P.; BEUCHAT, L.R. \& MONTVILLE, T.J. - Food microbiology fundamentals and frontiers. Washington, ASM, 1997. p. 228-264.

17. PAIVA, M.P. - Recursos pesqueiros estuarinos e marinhos do Brasil. Fortaleza, Edições UFC, 1997.

18. POPOFF, M.; BOCKEMUHL, J.; BRENNER, F.W. \& GHEESLING, L.L. - Supplement 200 (no. 44) to the Kauffmann-White scheme. Res. Microbiol., 152: 907-909, 2001.

19. REINHARD, R.G.; McADAM, T.J.; FLICK, G.J. et al. - Analisys of Campylobacter jejuni, Campylobacter coli, Salmonella, Klebsiella pneumoniae, and Escherichia coli O157:H7 in fresh hand-picked blue crab (Callinectes sapidus) meat. J. Food protect., 59: $803-807,1996$.
20. RODRIGUES, D.P. - Relatório anual de atividades de monitoramento da resistência antimicrobiana em Enteropatógenos. Rio de Janeiro, CGLAB/CENEPI/FUNASA/ MS, 2002.

21. RODRIGUES, D.P. - Relatório anual de atividades de monitoramento da resistência antimicrobiana em Enteropatógenos. Rio de Janeiro, CGLAB/CENEPI/FUNASA/ MS, 2003.

22. SANTOS, L.R.; NASCIMENTO, V.P.; FLORES, M.L. et al. - Salmonella Enteritis isoladas de amostras clínicas de humanos e de alimentos envolvidos em episódios de toxinfecções alimentares, ocorridas entre 1995 e 1996, no Estado do Rio Grande do Sul. Hig. Aliment., 16: 93-99, 2002.

23. SPELLBERG, B.; POWERS, J.H.; BRASS, E.P.; MILLER, L.G. \& EDWARDS Jr., J.E - Trends in antimicrobial drug development implications for the future. Clin. infect. Dis., 38: 1279-1286, 2004.

24. TAVECHIO, A.T.; GHILARDI, A.C.R.; PERESI, J.T. et al. - Salmonella serotypes isolated from nonhuman sources in São Paulo, Brazil, from 1996 through 2000. J. Food protect., 65: 1041-1044, 2002.

25. THEOPHILO, G.N.D. \& VIEIRA, R.H.S.F. - Pesquisa de Vibrio parahaemolyticus em caranguejos crus e cozidos comercializados na Praia do Futuro (Fortaleza, CE). Bol. SBCTA, 28: 134-142, 1994

26. VIEIRA, R.H.S.F. \& IARIA, S.T. - Vibrio parahaemolyticus in lobster Panulirus laevicauda (Latreille). Rev. Microbiol. (S. Paulo), 24: 16-21,1993.

27. WEGENER, H.C. - Exchange of bacteria between animals and humans. In: International Meeting on Bacterial Epidemiological Markers, 5., IMBEM. Netherlands, 2000. p. 29.

28. WONG, H.C.; CHEN, M.C.; LIU, S.H. \& LIU, D.P. - Incidence of highly genetically diversified Vibrio parahaemolyticus in seafood imported from Asian countries. Int. J. Food Microbiol., 52: 181-188, 1999.

Received: 27 February 2004

Accepted: 13 July 2004 